\title{
An Internally Controlled Virion PCR for the Measurement of HIV-1 RNA in Plasma
}

\author{
V. Natarajan, R.J. Plishka, E.W. Scott, H.C. Lane, ${ }^{1}$ and N.P. Salzman
}

Laboratory of Molecular Retrovirology, Deptartment of Microbiology, Georgetown University, Washington, D.C. 20007;

${ }^{1}$ National Institute of Allergy and Infectious Diseases, Bethesda, Maryland 20892

\begin{abstract}
We have developed an assay to measure the HIV-1 RNA in patients' plasma or sera using an infectious mutant virus as an internal control. The mutant virus VX-46 has a 25-bp insert in a conserved region between the primer-binding and major splice donor sites. To utilize this virus as an internal control, different dilutions of this virus were added to aliquots of plasma sample to be measured, RNA was isolated and reverse-transcribed to CDNA. PCR was performed with primers selected to include the sequences on either side of the insert contained in the externally added virus. The DNA product from the control virus is 25 bp longer than that from the virus present in plasma. The amount of viral RNA present in a plasma sample is calculated after the PCR-amplified products are separated by gel electrophoresis. Unlike other quantitative PCR assays, this internally controlled virion PCR (ICVPCR) assay eliminates errors introduced by variable recovery during the RNA purification step, therefore, enhancing the accuracy of the assay.
\end{abstract}

$\mathbf{Q}$ uantitative PCR has been used to measure the relative levels of RNA and DNA from a variety of different samples. Under ideal conditions a direct correlation can be found between the amount of starting target material and the amount of PCR product. ${ }^{(1-3)}$ However, this is often not the case for clinical samples owing to the presence of inhibitors of PCR in samples and differing efficiencies in sample recovery and kinetics of PCR. ${ }^{(4-7)}$ Small variations in amplification efficiency can change the yield of the product and make it difficult to accurately estimate the amount present in the starting material. ${ }^{(8)}$ To avoid these problems, several laboratories have described the use of internal standards in PCR. ${ }^{(8-14)}$ Generally, the internal standard DNA or RNA share the same primers as the target DNA or RNA but will contain either a deletion or an insertion so that the products obtained from the standard and targe, can be distinguished.

A variation in the use of an internal control is the competitive PCR procedure. ${ }^{(8)}$ In this method varying known amounts of the internal standards are added to equal aliquots of the sample containing the unknown target sequence. The internal standard and the target sequence compete equally for primer binding and amplification in the PCR. Variables such as the efficiency of amplification and the number of cycles will have the same effect on both templates. Equal amounts of products will be formed when the initial concentrations of the templates are equal. Experimentally, the ratio of products formed can be determined and the equivalence point can be calculated. This method has been successfully employed to quantify the amount of HIV-1 RNAs in clinical samples. ${ }^{(15,16)}$ However, this method does not control the variations in RNA recovery from sample to sample. Here, we report a modified method in which an infectious HIV-1 mutant virus was used as the source of competitor RNA. Different amounts of the mutant virus were added to equal aliquots of the sample containing an unknown amount of virus and RNA extraction and reverse transcriptase PCR (RT-PCR) were carried out in a manner that allowed for relatively precise quantitaion of the amount of viral RNA present in the sample.

\section{MATERIALS AND METHODS \\ Cells}

Cells (293) were obtained from ATCC and maintained in MEM medium containing $10 \%$ fetal calf serum. MT- 2 cells were obtained from Dr. D. Richman through the National Institute of Allergy and Infectious Diseases (NIAID) AIDS research program and were maintained in RPMI 1640 medium containing 10\% fetal calf serum. ${ }^{(17)}$

\section{Ceneration of Mutant HIV-1 Virus}

A well-conserved region between the primer-binding and gag initiation sites of HIV-1 was chosen for insertion. ${ }^{(18)}$ The plasmid pNL4.3, an infectious molecular clone of HIV-1 obtained from Dr. M. Martin, was used as the starting material. ${ }^{(19)}$ A mutant (VX-46) with the insert 5'-AGACATCTAGACGCGTCTAGACGCG-3' at nucleotide position 715 of pNL4.3 was generated using standard procedures as described in Sambrook et al. ${ }^{(20)}$ The HIV-1 nucleotide numbering system used is according to HIVNL4.3 
(GenBank accession number M19921). The VX-46 DNA was transfected into 293 cells by the calcium phosphate precipitation method. ${ }^{(20)}$ Forty-eight hours after transfection, the culture fluid was taken and used to infect MT- 2 cells. The mutant virus grew with similar kinetics as that of wild-type virus (V. Natarajan, unpubl.), and the cell-free virus was harvested, aliquoted, and stored at $-70^{\circ} \mathrm{C}$. Each aliquot was used once in internally controlled virion PCR (ICVPCR) experiments. The amount of virus in the culture supernatant was estimated by p24 antigen ELISA assay using Coulter Corp. (Hialeah, FL) reagents following the manufacturer's recommended protocol.

\section{PCR Primers}

The ICVPCR primers described in Table 1 were synthesized with an Applied Biosystems Inc. DNA synthesizer (Foster City, CA).

\section{RNA Isolation and CDNA Synthesis}

After informed consent was obtained, whole-blood samples were collected from HIV-1 seropositive patients in the presence of acid citrate dextrose as an anticoagulant. The plasma was separated by centrifugation and stored at $-70^{\circ} \mathrm{C}$ until use. Aliquots $(100 \mu \mathrm{l})$ of serial dilutions of the mutant virus VX-46 were added to $100 \mu \mathrm{l}$ of patient's plasma, and RNA was extracted with $4.0 \mathrm{~m}$ guanidium thiocyanate and phenol in the presence of $180 \mathrm{~mm}$ sodium acetate as described earlier. ${ }^{(21)}$ The RNA was precipitated by addition of an equal volume of isopropanol and $10 \mu \mathrm{g}$ of carrier tRNA (Sigma Chemical Co.).

RNA was recovered by centrifugation, washed with cold $70 \%$ ethanol, dissolved in $8.0 \mu$ l of DNase buffer containing $50 \mathrm{~mm}$ Tris ( $\mathrm{pH} 8.0$ ), $5 \mathrm{~mm} \mathrm{MgCl}_{2}$, and 10 units of RNase-free DNase (Boehringer Mannheim Biochemicals), and incubated at $25^{\circ} \mathrm{C}$ for $30 \mathrm{~min}$. The DNase was inactivated at $80^{\circ} \mathrm{C}$ for $10 \mathrm{~min}$, and the RNA was used for cDNA synthesis using a cDNA cycle kit obtained from Invitrogen Corporation (San Diego, CA). Briefly, $2 \mu \mathrm{l}$ of $100 \mathrm{~mm}$ methyl mercuric hydroxide was added to $8 \mu$ l of RNA, and after $5 \mathrm{~min}$ of incubation at room temperature, $2.5 \mu \mathrm{l}$ of $0.7 \mathrm{M} \beta$-mercaptoethanol was added and the reaction was kept on ice. To this was added $4.0 \mu \mathrm{l}$ of $5 \times$ RT buffer $(0.5 \mathrm{M}$ Tris at $\mathrm{pH} 8.3,0.2 \mathrm{M}$
TABLE 1 Oligonucleotide Deoxyribonucleotide Primer Sequences Used in PCR

\begin{tabular}{|c|c|c|}
\hline Primer & Sequence & Position in HIVNL4.3 \\
\hline ICVPCR-9 & 5'-T CCCT GCT T GCCCAT ACT A -3' & 890-908 (complementary) \\
\hline ICVPCR-16 & 5'-AT CT CT CGACGCA GGACT -3' & $681-698$ \\
\hline ICVPCR-17 & 5'-GCT CT CGCACCCA T CT CT -3' & 786-803 (complementary) \\
\hline ICVPCR-18 & 5'-ACTAGCGGA GGCT A GAAGGA-3' & $765-784$ \\
\hline
\end{tabular}

$\mathrm{KCl}, 50 \mathrm{~mm} \mathrm{MgCl}_{2}$ ), $1.0 \mu \mathrm{l}$ of RNase inhibitor, $1.0 \mu \mathrm{l}$ of $25 \mathrm{~mm}$ of the dNTPs, 1.0 $\mu l$ of primer ICVPCR-9 (40 pmoles), and $0.5 \mu \mathrm{l}$ of AMV reverse transcriptase (5 units), and it was incubated at $42^{\circ} \mathrm{C}$ for 1 hr. The reaction was then heated to $95^{\circ} \mathrm{C}$ for $3 \mathrm{~min}$ and cooled on ice for $2 \mathrm{~min}$, five more units of reverse transcriptase were added, and the incubation was continued for another hour at $42^{\circ} \mathrm{C}$. Finally, the reaction was heated to $95^{\circ} \mathrm{C}$ for 3 min, and the cDNA was either used in the PCR or stored at $-20^{\circ} \mathrm{C}$.

\section{PCR}

Five microliters of cDNA was used in a reaction containing $10 \mathrm{mM}$ Tris- $\mathrm{HCl}$ at

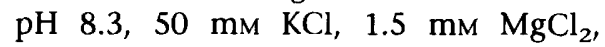
$0.001 \%$ gelatin, $0.2 \mathrm{~mm}$ dNTPs, 25 pmoles of primers ICVPCR-16 and ICVPCR-17, and 2.5 units of Taq DNA polymerase (Perkin-Elmer Cetus) in a final volume of $50 \mu \mathrm{l}$. The samples were amplified in a Perkin-Elmer Cetus thermocycler (9600) with the following PCR cycle program: one cycle at $94^{\circ} \mathrm{C}$ for 60 $\mathrm{sec}, 55^{\circ} \mathrm{C}$ for $10 \mathrm{sec}$, and $72^{\circ} \mathrm{C}$ for $30 \mathrm{sec}$; 30 cycles at $94^{\circ} \mathrm{C}$ for $15 \mathrm{sec}, 55^{\circ} \mathrm{C}$ for 30 $\mathrm{sec}, 72^{\circ} \mathrm{C}$ for $60 \mathrm{sec}$, and a final incubation at $72^{\circ} \mathrm{C}$ for $10 \mathrm{~min}$. The samples were then stored at $4^{\circ} \mathrm{C}$ until analysis. The competitor plasmid (pA1) DNA used to estimate the amount of cDNA from VX-46 virus contained pNL4.3 nucleotide sequences from 501 to 1448 .

\section{Analysis of the PCR Product}

Fifteen microliters of PCR product was hybridized with $5^{\prime}{ }^{32} \mathrm{P}$-labeled oligonucleotide ICVPCR-18, separated in a $10 \%$ polyacrylamide gel, and autoradiographed as described earlier. ${ }^{(22)}$ The amount of radioactivity present in each band was quantitated using either the Molecular Dynamics PhosphorImager (Sunnyvale, CA) or Fuji Medical Systems BAS1000 (Stamford, CT) by exposing the gel to a storage Phosphor screen as described by Johnston et al. ${ }^{(23)}$

\section{RESULTS AND DISCUSSION Estimation of RNA Present in a VX-46 Virus Preparation}

RNA was isolated from aliquots of VX-46 virus containing $100 \mathrm{pg}, 25 \mathrm{pg}$, or $500 \mathrm{fg}$ of p24 antigen, and cDNA was synthesized using standard conditions. To establish and standardize the assay, cDNA from VX-46 virus was PCR-amplified in the presence of different amounts of plasmid DNA (pA1) containing pNL4.3 nucleotide sequences from 501 to 1448 . As shown in Figure 1, the primers selected gave the predicted 123 - and 148bp DNA PCR products from the wildtype and mutant viral sequences, respectively. In some experiments additional minor bands were seen. Most likely these are heteroduplexes formed between the two expected bands. Also,

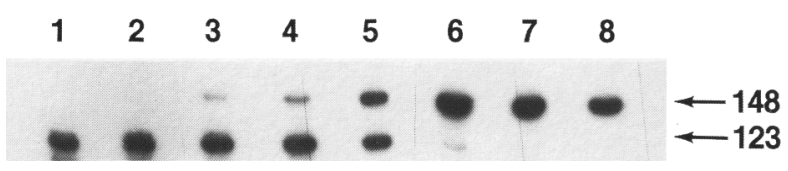

FIGURE 1 Use of cDNA synthesized from mutant virus (VX-46) RNA as competitor in PCR. RNA isolated from the mutant virus containing $100 \mathrm{pg}$ of p24 antigen was used to synthesize cDNA in a $60-\mu l$ reaction. Two microliters of the cDNA was used in the PCR containing various amounts of competitor wild-type DNA (pA1) containing HIVNL4.3 sequences from 501 to 1448 . The PCR was carried out, and the products were hybridized with a ${ }^{32} \mathrm{P}$-labeled probe and autoradiographed as described in Materials and Methods. The competitor DNAs present in the reactions were $10^{6}$ (lane 1$) ; 5 \times 10^{5}$ (lane 2); $10^{5}$ (lane 3 ); $5 \times 10^{4}$ (lane 4 ); $10^{4}$ (lane 5); $10^{3}$ (lane 6 ); $10^{2}$ (lane 7 ); and 0 (lane 8 ) copies. The sizes shown (right) were the PCR products in base pairs from mutant and wild-type sequences, respectively. 

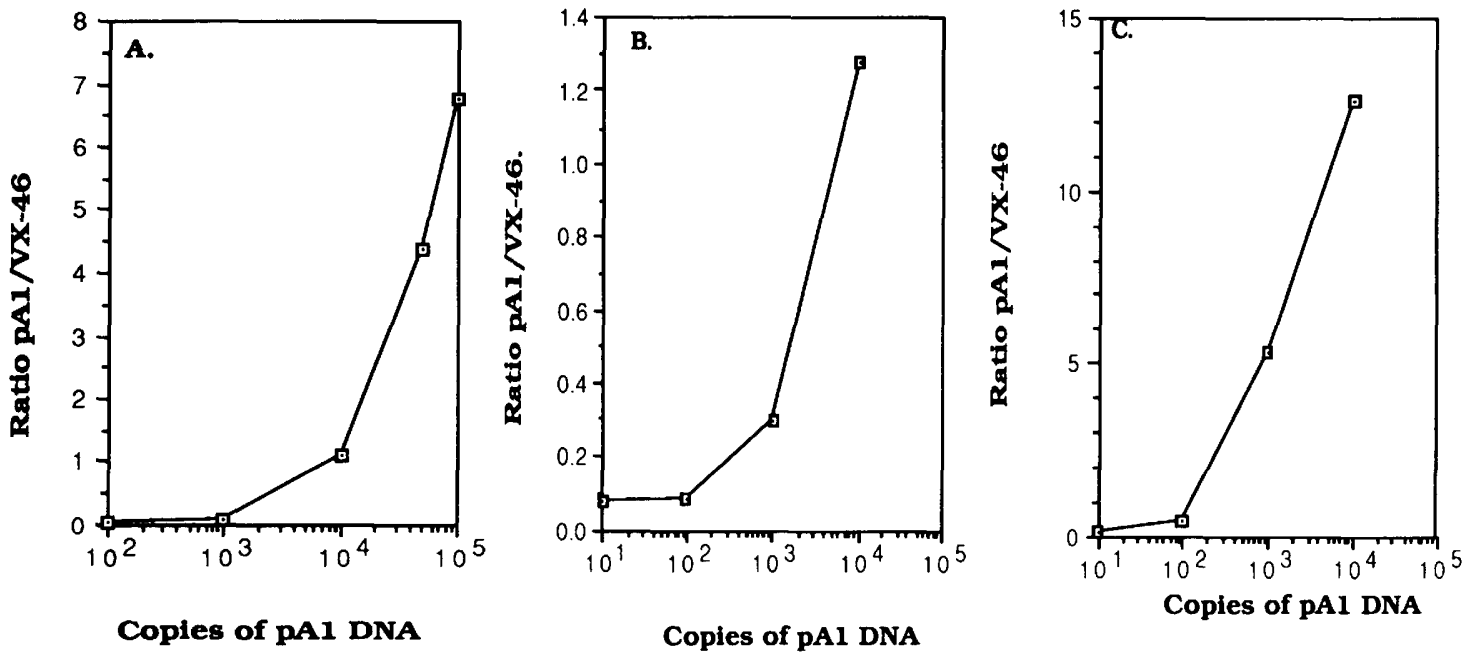

FIGURE 2 Estimation of the RNA isolated from the mutant virus VX-46. The amount of radioactivity present in bands corresponding to wild-type and mutant PCR products was estimated by exposing it to a storage Phosphor screen and quantitated using a Molecular Dynamics PhosphorImager. ${ }^{(23)}$ The ratio between the amount of radioactivity present in wild-type (pA1) and mutant (VX-46) DNA bands was plotted against the amount of wild-type DNA used in the PCR. The mutant viral RNA was isolated from virus containing $100 \mathrm{pg}(A), 25 \mathrm{pg}(B)$, and $500 \mathrm{fg}(C)$ of p24 antigen, respectively. The data derived from Fig. 1 are shown in $A$. The RNA isolated from virus containing $25 \mathrm{pg}(B)$ and 500 fg $(C)$ of p24 was used to synthesize cDNA in a 40- $\mu$ l reaction, and $3 \mu \mathrm{l}$ of cDNA was used in competitive PCR. Based on the method described by Menzo et al., ${ }^{(16)}$ we calculate that $2 \mu \mathrm{l}$ of cDNA in $A$ has $9500,3 \mu \mathrm{l}$ of cDNA in $B$ has 5200 , and $3 \mu \mathrm{l}$ of cDNA in $C$ has 120 copies, respectively.

the unused excess primer from the cDNA synthesis step can participate in the PCR reaction and generate a longer product (seen in Figs. 3 and 4, below). These bands do not interfere with accurate quantitation because the quantitation by this method is based on relative levels of bands from target and competitive templates and not on the absolute amounts. ${ }^{(24)}$ The amounts of radioactivity in the specific bands were determined as described in Materials and methods. The ratios between the amounts of radioactivity present in wild-type and mutant DNA bands were plotted as described earlier. ${ }^{(15)}$ On the basis of these data (Fig. 2), we calculated that 285,000 , 69,300 , and 1600 copies of RNA were isolated from virus containing $100 \mathrm{pg}, 25$ $\mathrm{pg}$, and $500 \mathrm{fg}$ of p24 antigen, respectively.

Based on the mass of an HIV-1 particle, a virus preparation with $100 \mathrm{pg}$ of p24 would be calculated to contain 1 million HIV particles, ${ }^{(25,26)}$ or 2 million copies of RNA. Thus, the copy numbers determined in our experiment represent $\sim 15 \%$ of the theoretical value. This reflects loss of RNA during extraction and lower than the theoretical yields in the preparation of cDNA. However, the quantitation by competitive PCR relies on the relative levels of wild-type and mutant templates, rather than the absolute amount. Therefore, once the deter- mination of the amount of RNA in a mutant virus preparation is made, the recovery of RNA in each ICVPCR experiment does not affect the outcome of the results.

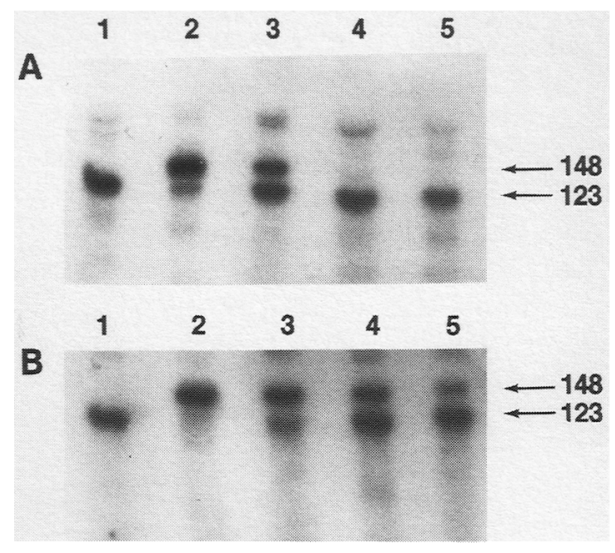

\section{ICVPCR to Determine the Level of HIV-1 RNA in Plasma}

Using this standardized VX-46 virus as the competitor during the RNA isolation,

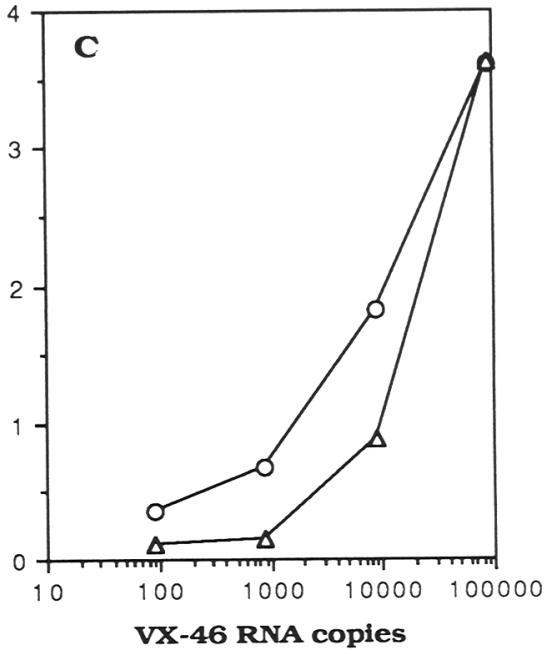

FIGURE 3 ICVPCR for the estimation of HIV-1 RNA in patient's plasma. To $100 \mu \mathrm{l}$ aliquots of patient's plasma, different dilutions of mutant virus (VX-46) containing 0 (lane 1), 30 (lane 2), 3 (lane 3), 0.3 (lane 4), and 0.03 (lane 5) pg of p24 antigen were added. RNA isolation, cDNA synthesis, and PCR were carried out as described in Materials and Methods. The size of DNA products from mutant (148) and wild type (123) are shown (right). (A, B) Plasma from two different patients. $(C)$ Estimation of HIV-1 RNA in patient's plasma. The radioactivity present in each band was quantitated using a Molecular Dynamics PhosphorImager. The ratio between the radioactivity present in mutant and patient DNA bands was plotted against the amount of mutant viral RNA added to the patient's plasma during RNA isolation. The mutant viral RNA copy numbers were calculated using the average value ( 2900 copies of RNA per picogram of p24 antigen) obtained with the data shown in Fig. 2. Patient $1(\triangle)$ has 8800 copies; patient $2(O)$ has 1600 copies of RNA in $100 \mu \mathrm{l}$ of plasma. 


\section{IIIIIIIResearch}
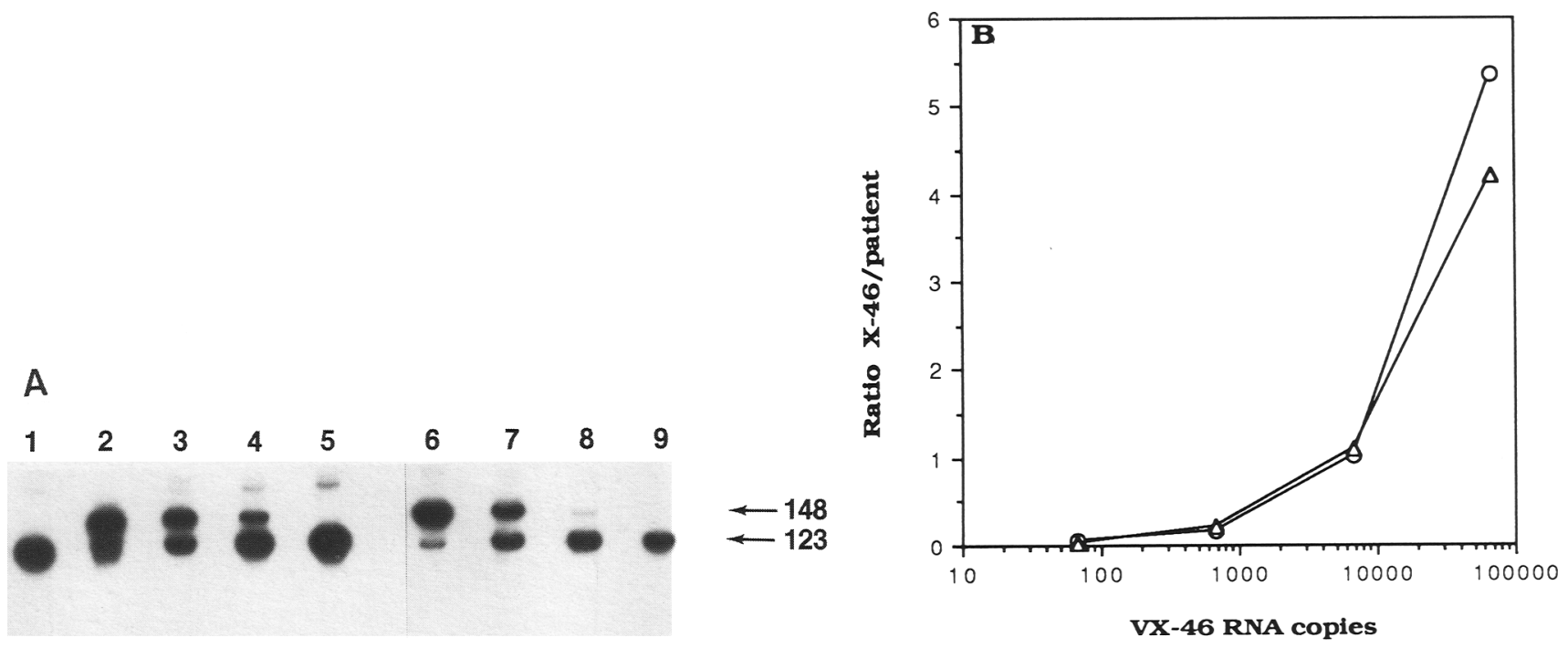

FIGURE 4 Reproducibility of ICVPCR. $(A)$ To $100 \mu$ l aliquots of patient's plasma, different dilutions of mutant virus (VX-46) containing 0 (lane 1 ), 24 (lanes 2,6), 2.4 (lanes 3,7), 0.24 (lanes 4,8), and 0.024 (lane 5,9) pg of p24 antigen were added. RNA isolation, cDNA synthesis, PCR, and gel analysis for lanes 1-5 and 6-9 were carried out by two separate experiments on different days. The sizes of DNA products from mutant (148) and wild type (123) are shown on the right. $(B)$ The radioactivity present in each band was quantitated and plotted as described in Materials and Methods. The data for $\triangle$ were from lanes $2-5$; that for $\bigcirc$ were from lanes $6-9$.

the amount of HIV-1 viral RNA in a patient's plasma was estimated. The results obtained with two different plasma samples are shown in Figure 3. The amount of radioactivity present in each band was estimated, and the ratio between the amount of radioactivity present in the mutant and wild-type (patient) DNA bands was plotted against the input mutant viral RNA. Using this technique, the amounts of viral RNA present in the samples were determined to be 88,000 and 16,000 copies of RNAs per milliliter of plasma from patients 1 and 2 , respectively (Fig. 3C).

The reproducibility of the ICVPCR method was then assessed. The amount of viral RNA in a plasma sample was estimated by performing the entire assay on two different days. The amount of RNA by these two estimates were 60,000 and 68,000 copies per milliliter of plasma (Fig. 4), demonstrating that the ICVPCR method is reliably reproducible.

Competitive RNA PCR has been used successfully for the estimation of the levels of HIV-1 viral RNA present in patient samples. ${ }^{(27,28)}$ In this procedure, the ratio of the amplified products is affected equally by the factors that influence the PCR. However, it lacks a control for the RNA purification step. It has been estimated that, on average, $36 \%$ of the RNA sample can be lost as a result of the ex- traction procedures used. ${ }^{(28)}$ To account for the variable loss of RNA when gene expression is studied using RNA extracted from cells, the RNA expressed by the gene under study is often compared with another RNA species that is constitutively expressed. ${ }^{(29,30)}$ However, such a control RNA is not available in plasma. By adopting the modified method described in this report, the mutant virion RNA can serve both as a control for the RNA extraction procedure and as a competitive RNA template in the PCR.

\section{ACKNOWLEDGMENTS}

This work was supported with federal funds from NIAID, National Institutes of Health (NIH), (contract NO1-A1-05058). The following reagent was obtained through AIDS research and reference reagent program, division of AIDS, NIAID, NIH: MT-2 cells were from Dr. D. Richman. We thank Dr. M. Martin for providing the plasmid pNL4.3. The technical help of N. Caffo is greatly appreciated. We thank A. Lord for help in using the PhosphorImager, J.A. Metcalf for providing the patient samples, and $P$. Lee for typing the manuscript.

\section{REFERENCES}

1. Mullis, K.B. and F.A. Faloona. 1987. Specific synthesis of DNA in vitro via a poly- merase-catalyzed chain reaction. Methods Enzymol. 155: 335-350.

2. Ferre, F. 1992. Quantitative or semi-quantitative PCR: Reality versus myth. $P C R$ Methods Applic. 2: 1-9.

3. Sardelli, A.D. 1993. Plateau effect-Understanding PCR limitations. Amplifications: Forum PCR Users 9: 1-5.

4. Holodniy, M., S. Kim, D. Katzenstein, M. Konrad, E. Groves, and T.C. Merigan. 1991. Inhibition of human immunodeficiency virus gene amplification by heparin. J. Clin. Microbiol. 29: 676-679.

5. Beutler, E., T. Gelbart, and W. Kuhl. 1990. Interferences of heparin with the polymerase chain reaction. BioTechniques 9: 166.

6. de Franchis, R., N.C.P. Cross, N.S. Foulkes, and T.M. Cox. 1988. A potent inhibitor of Taq polymerase copurifies with human genomic DNA. Nucleic Acids Res. 16: 10355.

7. Coutlée, F., P. Saint-Antoine, C. Olivier, A. Kessous-Elbaz, H. Voyer, F. Berrada, P. Bégin, L. Giroux, and R. Viscidi. 1991. Discordance between primer pairs in the polymerase chain reaction for detection of human immunodeficiency virus type 1: A role for taq polymerase inhibitors. $J$. Infect. Dis. 164: 817-818.

8. Gilliland, G., S. Perrin, K. Blanchard, and H.F. Bunn. 1990. Analysis of cytokine mRNA and DNA: Detęction and quantitation by competitive polymerase chain reaction. Proc. Natl. Acad. Sci. 87: 27252729.

9. Wang, A.M., M.V. Doyle, and D.F. Mark. 
1989. Quantitation of mRNA by the polymerase chain reaction. Proc. Natl. Acad. Sci. 86: 9717-9721.

10. Becker-André, M. and K. Hahlbrock. 1989. Absolute mRNA quantification using the polymerase chain reaction (PCR). A novel approach by a PCR aided transcript titration assay (PATTY). Nucleic Acids Res. 17: 9437-9446.

11. Chelly, J., D. Montarras, C. Pinset, Y. Berwald-Netter, J.-C. Kaplan, and A. Kahn. 1990. Quantitative estimation of minor mRNAs by cDNA polymerase chain reaction. Application to dystrophin mRNA in cultured myogenic and brain cells. Eur. J. Biochem. 187: 691-698.

12. Bergenhem, N.C.H., P.J. Venta, P.J. Hopkins, J.K. Hyung, and R.E. Tshian. 1992. Mutation creates an open reading frame within the $5^{\prime}$ untranslated region of macaque erythrocyte carbonic anhydrase (CA) I mRNA that suppresses CA I expression and supports the scanning model for translation. Proc. Natl. Acad. Sci. 89: 8798-8802.

13. Aoki-Sei, S., R. Yarchoan, S. Kageyama, D.T. Hoekzema, J.M. Pluda, K.M. Wyvill, S. Broder, and H. Mitsuya. 1992. Plasma HIV-1 viremia in HIV-1 infected individuals assessed by polymerase chain reaction. AIDS Res. Hum. Retroviruses 8: 12631270.

14. Siebert, P.D. and J.W. Larrick. 1992. Competitive PCR. Nature 359: 557-558.

15. Bagnarelli, P., S. Menzo, A. Manzin, M. Giacca, P.E. Varaldo, and M. Clementi. 1991. Detection of human immunodeficiency virus type 1 genomic RNA in plasma samples by reverse-transcription polymerase chain reaction. J. Med. Virol. 34: 89-95.

16. Menzo, S., P. Bagnarelli, M. Giacca, A. Manzin, P.E. Varaldo, and M. Clementi. 1992. Absolute quantitation of viremia in human immunodeficiency virus infection by competitive reverse transcription and polymerase chain reaction. J. Clin. Microbiol. 30: 1752-1757.

17. Harada, S., Y. Koyanagi, and N. Yamamoto. 1985. Infection of HTLV-III/LAV in HTLV-I-carrying cells MT-2 and MT-4 and application in a plaque assay. Science 229: 563-566.

18. Myers, G., B. Korber, J.A. Berzofsky, R.F. Smith, and G.N. Pavlakis. 1992. "Human retroviruses and AIDS: A compilation and analysis of nucleic acid and amino acid sequences." Los Alamos National Laboratory, Los Alamos, NM.

19. Adachi, A., H.E. Gendelman, S. Koenig, T. Folks, R. Willey, A. Rabson, and M.A. Martin. 1986. Production of acquired immunodeficiency syndrome-associated retrovirus in human and nonhuman cells transfected with an infectious molecular clone. J. Virol. 59: 284-291.

20. Sambrook, J., E.F. Fritsch, and T. Maniatis.
1989. Molecular cloning: A laboratory manual, 2nd ed. Cold Spring Harbor Laboratory Press, Cold Spring Harbor, New York

21. Chomczynski, P. and N. Sacchi. 1987. Single-step method of RNA isolation by acid guanidinium thiocyanate-phenol-chloroform extraction. Anal. Biochem. 162: 156159.

22. Psallidopoulos, M.C., S.M. Schnittman, L.M. Thompson III, M. Baseler, A.S. Fauci, H.C. Lane, and N.P. Salzman. 1989. Integrated proviral human immunodeficiency virus type 1 is present in $\mathrm{CD}^{+}$peripheral blood lymphocytes in healthy seropositive individuals. J. Virol. 63: 4626-4631.

23. Johnston, R.F., S.C. Pickett, and D.L Barker. 1990. Autoradiography using storage phosphor technology. Electrophoresis 11: 355-360.

24. Piatak Jr., M., K.-C. Luk, B. Williams, G.M. Shaw, and J.D. Lifson. 1993. Quantitative competitive PCR for accurate quantitation of HIV DNA and RNA species. BioTechniques 14: 70-80.

25. Bourinbaiar, A.S. 1991. HIV and Gag. Nature 349: 111.

26. Bourinbaiar, A.S. 1992. Weight of HIV. AIDS Res. Hum. Retroviruses 8: 1545.

27. Piatak Jr., M., M.S. Saag, L.C. Yang, S.J. Clark, J.C. Kappes, K.-C. Luk, B.H. Hahn, G.M. Shaw, and J.D. Lifson. 1993. High levels of HIV-1 in plasma during all stages of infection determined by competitive PCR. Science 259: 1749-1754.

28. Clementi, M., S. Menzo, P. Bagnarelli, A. Manzin, A. Valenza, and P.E. Varaldo. 1993. Quantitative PCR and RT-PCR in virology. PCR Methods Applic. 2: 191-196.

29. Green, M.R., R. Treisman, and T. Maniatis. 1983. Transcriptional activation of cloned human beta-globin genes by viral immediate-early gene products. Cell 35: $137-148$

30. Orkin, S.H., S.E. Antonarakis, and H.H. Kazazian Jr. 1984. Base substitution at position -88 in a beta-thalassemic globin gene. Further evidence for the role of distal promoter element ACACCC. J. Biol. Chem. 259: 8679-8681.

Received July 26, 1993; accepted in revised form January 11, 1994. 


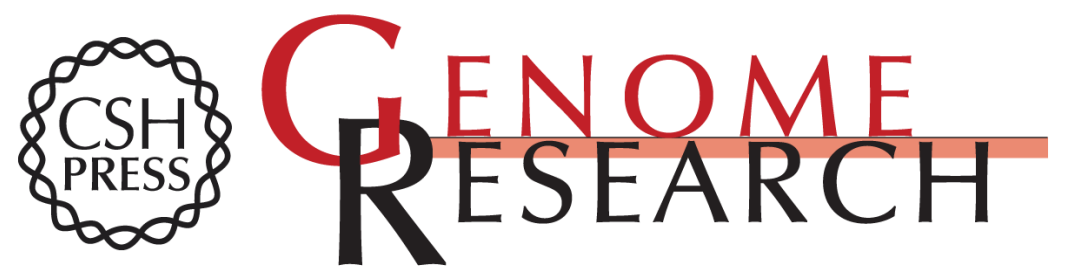

\section{An internally controlled virion PCR for the measurement of HIV-1 RNA in plasma.}

V Natarajan, R J Plishka, E W Scott, et al.

Genome Res. 1994 3: 346-350

References This article cites 28 articles, 10 of which can be accessed free at: http://genome.cshlp.org/content/3/6/346.full.html\#ref-list-1

\section{License}

Email Alerting

Receive free email alerts when new articles cite this article - sign up in the box at the Service top right corner of the article or click here.

\section{Affordable, Accurate Sequencing.}

To subscribe to Genome Research go to: https://genome.cshlp.org/subscriptions 